\title{
Change of soil quality based on humic acid with date palm compost incorporation
}

\author{
Hadda Ben Mbarek ${ }^{1} \cdot$ Imen Ben Mahmoud $^{1} \cdot$ Rayda Chaker $^{2} \cdot$ Hafedh Rigane $^{1} \cdot$ Sameh Maktouf $^{2} \cdot$ Aissa Arous $^{2}$. \\ Nabil Soua ${ }^{2} \cdot$ Mouna Khlifi ${ }^{2}$ Kamel Gargouri ${ }^{2}$ (i)
}

Received: 17 April 2018 / Accepted: 26 February 2019 / Published online: 13 March 2019

(c) The Author(s) 2019

\begin{abstract}
Purpose The most important factor affecting soil quality is soil humic fraction. Effects of adding carbon in soil humic compounds in arid environments have only been slightly investigated. The change in soil humic acids' structures in relation with manure and palm compost application and the evolution of humic acids' structures during palm composting have not been sufficiently investigated. The purpose of this study is to evaluate if date palm compost is suitable for the sustainable increase of soil carbon content with increasing soil humic compounds.

Methods Soil was amended with date palm compost and sheep manure, which represented two treatments, in addition to a control represented by unamended soil. Soil samples were taken from depth layers of 0-20 cm and $20-40 \mathrm{~cm}$. Physicochemical and spectroscopic analyses were used to study humic acids extracted from organic amendment and soil.

Results The neutral $\mathrm{pH}$ and the $\mathrm{C} / \mathrm{N}$ ratio of 11.9 revealed that the palm/manure compost was mature. Date palm compost application on soil showed its effectiveness in improving soil quality. Spectroscopic studies of humic compounds extracted from date palm compost and manure, showed the abundance of aromatic structures, confirmed by the low E4/E6 ratio associated with an increase in polycondensation and polymerization. Infrared spectroscopy of humic acids extracted from amended soil revealed its enrichment with aromatic structures.

Conclusions Using date palm compost for a short term suggests that this compost may be useful as an alternative to increase the soil fertility by increasing the humic acids quantity with enhancing aromaticity degree and functional groups.
\end{abstract}

Keywords Humic acids $\cdot$ Soil quality $\cdot$ Compost $\cdot$ Date palm waste $\cdot$ Manure

\section{Introduction}

Due to its role in preventing desertification and erosion, organic matter is a basic component of all agro-ecosystems. Organic matter is the result of the combined effect of incorporation, transformation and mineralization of plant and animal residues defined by the local soil and climate characteristics (Horwath 2015). Higher temperature levels accelerate organic matter decomposition; this is likely to cause a serious agriculture problem in the future (Conant et al. 2011).

Kamel Gargouri

kamel.gargouri@iresa.agrinet.tn

1 Earth Sciences Department, Faculty of Science Sfax, PO Box 1087, 3000 Sfax, Tunisia

2 Olive Institute, University of Sfax, PO Box 1087, 3000 Sfax, Tunisia
Several authors showed that soil in Tunisia suffer from low organic matter levels, especially in arid areas (Gargouri et al. 2013). Nevertheless, many organic farms in the Southeast of Tunisia have many problems such as higher soil salinity and low soil fertility (Kouki and Bouhaouach 2009). Among possible solutions, agronomists are looking for amendment of the natural ecosystem to improve the soil quality of agricultural land for crop production.

Among different organic amendments, animal manures offer a readily available solution to soil fertility problems (Eghball 2001). Moreover, a combination of manure with biosolids is considered the best management application for farmers (Rigane and Medhioub 2011).

In the Southeast of Tunisia, date palm is the dominant crop system for many farmers. Agronomists produce organic fertilizers based on date palm waste to protect the environment from palm waste and to enhance soil properties. To define the best management practices for farmers, it was 
necessary to examine soil properties for saving soil, money, time, and protecting the environment (Visser and Sterk 2007). Several authors such as Khiyami et al. (2008) found that the final compost based on date palm and crab wastes could be a good organic amendment. Ali (2008) reported that the addition of date palm compost enhances plant growth and germination. Benabderrahim et al. (2018) evaluated the palm trees' compost influence on alfalfa growth. They determined that this compost improves both of the minerals in alfalfa and soil properties. Therefore, using date palm compost increases soil fertility. Yet, effects of adding carbon in the stable soil humic fractions in arid environments have only been slightly investigated. In fact, the most important factor affecting soil quality is soil humic compounds (Xu et al. 2007). They enhance the life of $\mathrm{N}$ and $\mathrm{P}$ in soil, improve soil aggregates and stimulate plant respiration in soil (Hernandez et al. 2001).

To the best of our knowledge, no work has investigated if date palm compost mixed with animal manure increases soil humic acid compounds for a short term in arid soils. In fact, change in the humic acids' structures in relation with manure and palm compost application and the evolution of humic acids' structures during palm composting have not been sufficiently investigated.

In this paper, physical and chemical properties and structures of humic acids from manure, date palm compost (34\% date palm waste and $66 \%$ manure) and from soil were used to evaluate compost maturity and soil quality. Humic compounds' evolution in soil and amendments were studied using UV-visible and infrared spectroscopy. Thus, this study aimed to evaluate soil quality after short-term incorporation of palm composts. On the other hand, this work aimed to evaluate if date palm compost is suitable for a sustainable increase of soil carbon content.

\section{Materials and methods}

\section{Study area and sampling}

The field study was done in part of an organic farm that had a composting unit located in the oasis of Chenini, along the coast of the Gulf of Gabes $\left(33^{\circ} 53^{\prime} \mathrm{N}, 10^{\circ} 03^{\prime} \mathrm{E}\right)$ in the Southeast of Tunisia. The climate of the region is a Mediterranean arid climate.

Three soil treatments were installed. The first plot was amended with $10 \mathrm{~kg}$ of palm compost, while the second received $10 \mathrm{~kg}$ of manure and the last one was considered as a control soil without any amendment. The surface of each plot was $1.68 \mathrm{~m}^{2}$. The space between plots was about $1.0 \mathrm{~m}$. Soil plots were irrigated every 15 days. Organic amendments were incorporated into the soil and were mixed into a superficial soil layer $(0-20 \mathrm{~cm})$.
Samples' collection was made using an auger from two depth horizons $0-20 / 20-40 \mathrm{~cm}$. All the collected samples were air dried and passed through a $2 \mathrm{~mm}$ sieve prior to analytical work.

The compost used was produced in the integrated organic farm.

The raw materials of the compost were oasis palm wastes (34\%) and sheep manure (66\%). Composting was in windrow during 6 months until full maturity. Immature compost obtained after 3 months of composting process and mature one obtained after 6 months of composting were used. The manure used for the positive control was a sheep-goat type. For physical and chemical analyses, the amendments were air dried and crushed.

\section{Physical and chemical analyses}

The initial mixture, final compost and manure were analyzed. Each value determined the mean of three replications. $\mathrm{pH}$ and $\mathrm{EC}$ were measured in an amendment-water mixture with a ratio $(1: 5 \mathrm{w} / \mathrm{v})$ using a $\mathrm{pH}$ meter and conductivity meter (AME type 123 ) at $25^{\circ} \mathrm{C}$, respectively.

Dry matter (DM) content was measured by drying samples at $105^{\circ} \mathrm{C}$ until weight constancy; organic matter (OM) was determined by loss of weight on ignition at $400{ }^{\circ} \mathrm{C}$ in a muffle furnace providing the total organic matter content. The available phosphorus was measured calorimetrically (Pauwels et al. 1992). Total nitrogen analysis was performed using the Kjeldahl method. $\mathrm{Na}, \mathrm{Ca}$ and $\mathrm{K}$ content were determined first by extraction through heating amendment $(1.0 \mathrm{~g})$ with $\mathrm{HNO}_{3}(0.1 \mathrm{~N})$; then, the extract was analyzed by atomic absorption spectrophotometer (Pauwels et al. 1992).

Soil analyses were carried out before organic amendment application in soil and 3 months after. The Robinson pipette method and texture diagram (Jemagne 1967) were used to find particle size distribution and texture, respectively. Organic matter concentration was determined by carbon content and a conversion was done using the multiplication factor of 1.72. The Dichromate oxidation method (Walkley and Black method) was used for the determination of soil carbon concentration (Pauwels et al. 1992).

The extraction of humic compound from composts and manure was carried out using Tomati et al.'s (2001) method. Compost (2 g) was mixed with $\mathrm{NaOH}$ solution $(200 \mathrm{ml})$ and stirred. Humic fractions were obtained using centrifugation. The extract containing humic compounds was acidified by $\mathrm{HCl}$. After centrifugation, two fractions were obtained: FA (supernatant) and HA (precipitate). After $24 \mathrm{~h}$, the precipitated HA was dissolved in a $\mathrm{NaOH}$ solution at $\mathrm{pH} 12$ and was filtered to find a clear HA solution.

Soil humic acids were determined using the Rivero method (1998). Soil was stirred with $\mathrm{NaOH}$ and $\mathrm{Na}_{4} \mathrm{P}_{2} \mathrm{O}_{7}$ solutions. The HA was separated from the supernatant (FA) 
using centrifugation. The decreasing $\mathrm{pH}$ was achieved by adding $\mathrm{HCl}$ to the solution. The precipitated HA was separated by centrifugation, and then dissolved in $\mathrm{NaOH}$ and precipitated by adding $\mathrm{HCl}$ solution.

After extraction of HA and FA from different samples, the ratio of $\mathrm{HA}$ and $\mathrm{FA}$ fractions $\left(\mathrm{C}_{\mathrm{AH}} / \mathrm{C}_{\mathrm{AF}}\right)$ was calculated.

The obtained solution of different fractions was dialyzed to eliminate excess salt and finally lyophilized to perform a spectroscopic analysis.

\section{Spectroscopic analysis}

A mixture of $1 \mathrm{mg}$ humic acid with $400 \mathrm{mg}$ potassium bromide $(\mathrm{KBr})$ was used for infrared spectroscopy analysis. Spectra were determined for a wavelength between 4000 and $400 \mathrm{~cm}^{-1}$.

The E4/E6 ratio was determined by dissolving $3.0 \mathrm{mg} \mathrm{HA}$ in $0.05 \mathrm{M} \mathrm{NaHCO}_{3}$, adjusting the $\mathrm{pH}$ at 8.3 and by measuring at the absorbance at 465 and $665 \mathrm{~nm}$ by PerkinElmer model Lambda $15 \mathrm{UV}-\mathrm{Vis}$ spectrophotometer.

\section{Statistical analysis}

Mean comparison analyses using the ANOVA method were determined using SPSS 13.0 for windows (SPSS Inc.) Analysis of variance was calculated to determine changes in soil and amendment parameters using Duncan's multiple range tests at $5 \%$ level of significance $(P<0.05)$.

\section{Results and discussion}

\section{Palm compost and manure characterization}

The physical and chemical parameters of initial compost, mature compost and manure are determined (Table 1).

These parameters are useful for assessing compost maturity and stability (Raj and Antil 2011). Compost pH decreased during the composting process from 8.33 to 7.16 . A neutral $\mathrm{pH}$ indicates that compost is mature and stable (Gobat et al. 1998). This decrease can be explained by the release of organic acids with organic matter decomposition and/or $\mathrm{CO}_{2}$ solubilization (Ultra et al. 2005).

Compost characterized by $\mathrm{C} / \mathrm{N}$ ratio decreased from 29.12 to 11.40 at the last step of composting process. The value of $\mathrm{C} / \mathrm{N}$ ratio among 10 and 15 is assumed to be related to compost maturity (Aparna et al. 2008). Therefore, the date palm compost used was a mature one. Under the composting process, the $\mathrm{C}_{\mathrm{HA}} / \mathrm{C}_{\mathrm{FA}}$ ratio enhanced from 0.36 to 1.2. However, the $\mathrm{C}_{\mathrm{HA}} / \mathrm{C}_{\mathrm{FA}}$ ratio less than 1 indicated that the compost is not mature, which is contradictory to basic assessment using $\mathrm{C} / \mathrm{N}$ and $\mathrm{pH}$ indicators. The $\mathrm{C}_{\mathrm{HA}} / \mathrm{C}_{\mathrm{FA}}$ ratio was used for measuring humification level and for evaluating
Table 1 Physical and chemical characteristics of compost and manure

\begin{tabular}{lcrr}
\hline & Initial mixture & Final compost & \multicolumn{1}{l}{ Manure } \\
\hline Moisture (\%) & $64.15 \pm 0.01^{\mathrm{a}}$ & $38.88 \pm 0.03^{\mathrm{b}}$ & $14.80 \pm 0.62^{\mathrm{c}}$ \\
$\mathrm{DM}(\%)$ & $35.85 \pm 00^{\mathrm{c}}$ & $61.23 \pm 0.23^{\mathrm{b}}$ & $85.2 \pm 0.60^{\mathrm{a}}$ \\
$\mathrm{EC}(\mathrm{mS} / \mathrm{cm})$ & $7.30 \pm 0.21^{\mathrm{a}}$ & $6.55 \pm 0.43^{\mathrm{b}}$ & $7.13 \pm 0.06^{\mathrm{a}}$ \\
$\mathrm{pH}$ & $8.33 \pm 0.01^{\mathrm{a}}$ & $7.16 \pm 0.03^{\mathrm{c}}$ & $7.81 \pm 0.01^{\mathrm{b}}$ \\
$\mathrm{OM}(\%) / \mathrm{DM}$ & $85.36 \pm 0.05^{\mathrm{a}}$ & $47.85 \pm 0.04^{\mathrm{c}}$ & $48.20 \pm 0.6^{\mathrm{b}}$ \\
$\mathrm{TOC}(\%) / \mathrm{DM}$ & $49.52 \pm 0.02^{\mathrm{a}}$ & $18.59 \pm 0.01^{\mathrm{c}}$ & $21.43 \pm 0.04^{\mathrm{b}}$ \\
$\mathrm{TN}(\%) / \mathrm{DM}$ & $1.7 \pm 0.10^{\mathrm{a}}$ & $1.63 \pm 0.01^{\mathrm{a}}$ & $1.04 \pm 0.01^{\mathrm{b}}$ \\
$\mathrm{C} / \mathrm{N}$ & $29.12 \pm 0.02^{\mathrm{a}}$ & $11.40 \pm 0.06^{\mathrm{c}}$ & $20.6 \pm 0.16^{\mathrm{b}}$ \\
$\mathrm{C}_{\mathrm{HA}} / \mathrm{C}_{\mathrm{FA}}$ & $0.36 \pm 0.02^{\mathrm{b}}$ & $1.2 \pm 0.04^{\mathrm{a}}$ & Not determined \\
$\mathrm{MM}(\%)$ & $14.63 \pm 0.06^{\mathrm{c}}$ & $52.15 \pm 0.06^{\mathrm{a}}$ & $51.80 \pm 0.20^{\mathrm{b}}$ \\
$\mathrm{P}_{2} \mathrm{O}_{5}(\mathrm{mg} / \mathrm{kg})$ & $772.77 \pm 0.16^{\mathrm{c}}$ & $1086.91 \pm 0.09^{\mathrm{b}}$ & $1740.87 \pm 0.07^{\mathrm{a}}$ \\
$\mathrm{K}_{2} \mathrm{O}(\mathrm{mg} / \mathrm{kg})$ & $10,845 \pm 0.1^{\mathrm{b}}$ & $12,050 \pm 0.1^{\mathrm{a}}$ & $9640 \pm 1^{\mathrm{c}}$ \\
$\mathrm{Na}(\mathrm{mg} / \mathrm{kg})$ & $5250 \pm 0.1^{\mathrm{b}}$ & $7000 \pm 0.1^{\mathrm{a}}$ & $5000 \pm 2^{\mathrm{c}}$ \\
$\mathrm{Ca}(\mathrm{mg} / \mathrm{kg})$ & $20,000 \pm 0.1^{\mathrm{c}}$ & $38,000 \pm 0.1^{\mathrm{a}}$ & $21,000 \pm 1^{\mathrm{b}}$ \\
\hline
\end{tabular}

compost maturity (Ouatmane et al. 2002). Thus, assessment of compost maturity should be linked not only to $\mathrm{C} / \mathrm{N}$ ratio but also to humification degree. The compost used in this study was mature and the composting process is efficient. In addition, date palm compost had a high value of available potassium (1.2\%), and calcium (3.8\%), which are considered as important indicators of compost quality. The manure contained a high amount of phosphorus $(0.17 \%)$ as well as calcium $(2.1 \%)$, sodium $(0.96 \%)$ and nitrogen $(1.04 \%)$. The mature compost was of a good quality and met the German nutrient quality standards with the following nutrient contents: potassium $<2000 \mathrm{mg} / \mathrm{l}$, avail- $\mathrm{N}<300 \mathrm{mg} / \mathrm{l}$ and phosphate $<1200 \mathrm{mg} / \mathrm{l}$. These contents fall within the typical range for $\mathrm{K}$ between 0.6 and $1.7 \%$ and $\mathrm{Ca}$ between 1.0 and $4.0 \%$ (Lakhdar et al. 2009).

\section{Changes in soil properties after composting application}

Particle size distribution determined that both amended and control soils had low clay content of about $2.68 \%$, followed by silt content that was about $17.85 \%$, and the highest sandy content that was about $79.35 \%$. The experimental field had a sandy loam texture. Soil $\mathrm{pH}$ was not affected by manure or compost addition (Fig. 1). Soil depth did not affect the soil $\mathrm{pH}$. Results showed that the soil $\mathrm{pH}$ values remained above 7 for two amended soils. Organic amendments did not affect soil $\mathrm{pH}$ in both of the studied depths of the arid sandy soil that remained alcaline. Indeed, converse impacts were reported by several authors indicating that the incorporation of compost and manure for a long term increases (GarcíaGil et al. 2004) or decreases (Bastida et al. 2008) soils' pH, according to their initial $\mathrm{pH}$ and organic wastes. The buffering capacity could be linked to the high humic content of 
Unamended soil $\bigcirc$ Soil amended with compost
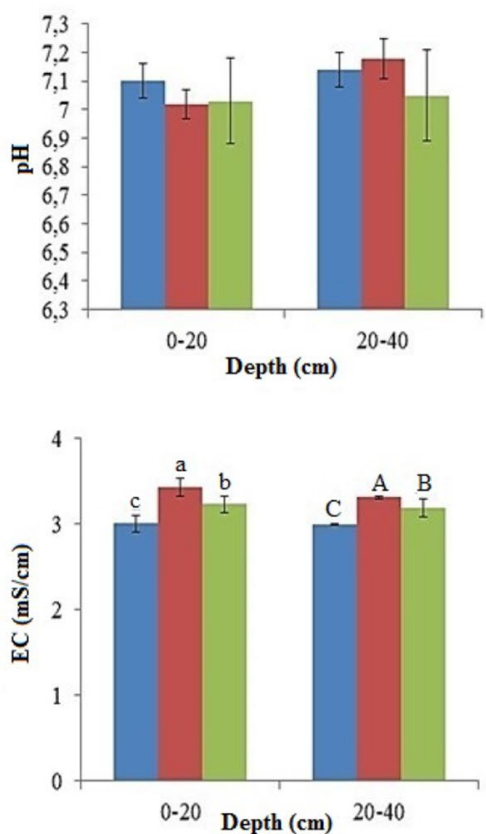
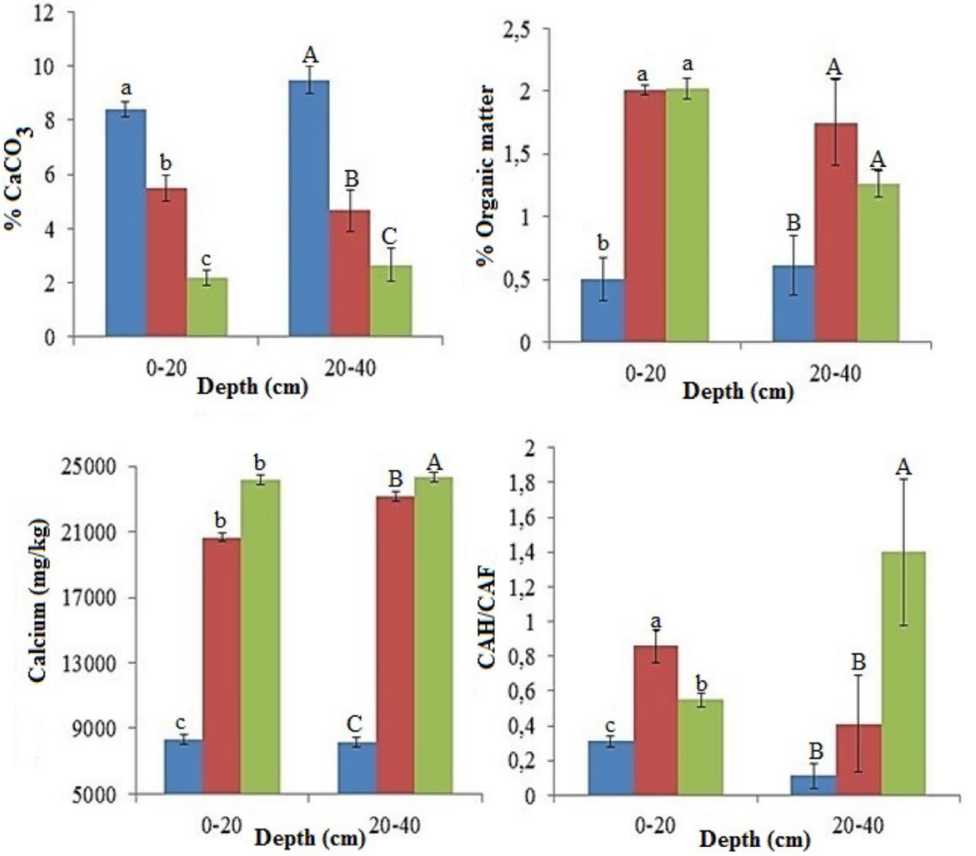

Fig. 1 Variation of soil properties with regard to treatment and depth. Lowercase letters indicate significance within 0-20 $\mathrm{cm}$ depth and capital letters indicate significance within 20-40 depth. Means with different letters indicate a significant difference at $P=0.05$

compost (García-Gil et al. 2004). Dikinya and Mufwanzala (2010) reported that soil $\mathrm{pH}$ did not change with the addition of irrespective dose of chicken manure.

The EC of the control soil was about $3 \mathrm{mS} / \mathrm{cm}$ (Fig. 1) with a slight increase in amended soil. This increase was remarkable in the soil amended by compost more than soil amended with manure in both the horizons $(0-20 \mathrm{~cm}$ and $20-40 \mathrm{~cm}$ ), although there was no major difference in EC values $(6.55 \mathrm{mS} / \mathrm{cm}$ for compost and $7.13 \mathrm{mS} / \mathrm{cm}$ for manure). The EC increase may be due to organic matter mineralization and transformation. It was reported that EC increases in soil after organic amendments incorporation such as compost and manure due to the addition of soluble salts and organic matter mineralization (Franco-Otero et al. 2011). The increase of EC was found in acidic as well as alkaline soils with the incorporation organic amendment of different natures (Sarwar et al. 2003).

The studied soil had a calcium carbonate content (Fig. 1) of almost $8 \%$ at the surface layer of $0-20 \mathrm{~cm}$ and $9 \%$ at the layer of $20-40 \mathrm{~cm}$. The application of organic amendments to the soil decreased calcium carbonate value. The amounts of $\mathrm{CaCO}_{3}$ in soil were $5 \%$ and $2 \%$ for compost and manure, respectively. This reduction was more in soil amended with manure than soil amended by compost. The decrease in $\mathrm{CaCO}_{3}$ values can be explained by the buffer soil response to acidification results to organic acids. Hemmat et al. (2010) also indicated the same phenomenon and observed a dosedependent effect. The $\mathrm{CaCO}_{3}$ dissolution was also determined by seasonal patterns in Mediterranean environments (Serrano-Ortiz et al. 2010).

The $\mathrm{CaCO}_{3}$ amended soil had a calcium content about $20.7(\mathrm{~g} / \mathrm{kg})$ and $24.2(\mathrm{~g} / \mathrm{kg})$ for compost and manure, respectively. The addition of organic amendment in soil might help increase calcium content in both the soil layers $(0-20 \mathrm{~cm}$ and 20-40 cm). In our situation, the increase of $\mathrm{Ca}^{2+}$ can be explained by soil $\mathrm{CaCO}_{3}$ dissolution (Fig. 1) becoming another source of $\mathrm{Ca}^{2+}$. Soil organic matter was the most responsible for soils' adsorbing power resulting in an improvement in the cation exchange capacity (CEC) and enhancing granulation. The soil organic matter decomposition process also contributes cations such as $\mathrm{Ca}^{2+}$ and $\mathrm{K}^{+}$ (Brady and Weil 2005).

The organic matter analysis for both depths showed that a low amount $(0.5 \%)$ was recorded in control soil', while soil organic matter reached $2 \%$ in amended soil for depth 0-20 cm and a value of $1.25 \%$ for depth $20-40 \mathrm{~cm}$. The amendment improved the organic matter concentration in soil surface layers with a slight migration in the deep layers. Soil organic matter concentration increased with compost incorporation in soils. The amendment addition clearly increases the level of SOM, which is in agreement with other authors (Heras et al. 2005). The SOM increased at the surface layer $(0-20 \mathrm{~cm})$ 
and showed a slight increase in the subsurface soil layer $(20-40 \mathrm{~cm})$. This can be explained by the addition of organic carbon and its migration into the soil. Soil chemical properties were improved by soil organic matter including nutrients' supply by mineralization and their availability to plants, cation exchange capacity and binding of heavy metals and pesticides (Stangel 1991).

Soil organic matter quality may be evaluated by the $\mathrm{C}_{\mathrm{HA}} /$ $\mathrm{C}_{\mathrm{FA}}$ ratio. Humic compounds can be indicative of aggradative or degradative development in soil (Valarini et al. 2003).

Results showed a clear increase of $\mathrm{C}_{\mathrm{HA}} / \mathrm{C}_{\mathrm{FA}}$ ratio after incorporation of palm compost and manure. This increase was greater with compost $(0.86 \%)$ in the surface soil layer $(0-20 \mathrm{~cm})$ and conversely with manure $(0.55 \%)$ in the deeper one (20-40 cm). The increase of ratio $\mathrm{C}_{\mathrm{HA}} / \mathrm{C}_{\mathrm{FA}}$ after compost incorporation can be an indication of enhancing carbon content associated with humic acid compounds (Rivero et al. 2004). Palm compost increased humic fractions in soil with increasing $\mathrm{C}_{\mathrm{AH}} / \mathrm{C}_{\mathrm{AF}}$.

Results showed that the compost was more efficient in boosting the humification process than manure. As regards the important role of humic compounds in the soil, compost could be considered as a better fertilizer than manure.

\section{Characterization of humic substances}

\section{Date palm compost and manure}

Humic acids were extracted from initially processed substrates, produced by palm compost and manure. E4/E6 ratios were used as indices to determine humic acids' molecular size. The value of this ratio was inversely proportional to the molecular size and the values are generally five times lower for humic compounds (Amir et al.2003; Sellami et al. 2008).

UV spectroscopy analysis of humic acids (Table 2) showed a high $\mathrm{E}_{4} / \mathrm{E}_{6}$ value of about 3.50 in the initial mixture. The E4/E6 ratio decreased to 2.27 in the final compost. The ratio was lower in the case of manure (2.08). Spectroscopic $\mathrm{E}_{4} / \mathrm{E}_{6}$ ratio parameters can be used to assess compost maturity and develop humic acids (Haddad et al. 2015). Tchegueni et al. (2013) reported that $\mathrm{E}_{4} / \mathrm{E}_{6}$ was 3.96 , at the beginning of the composting process and after 3 months, it stabilized at approximately 2.68. The lower value in manure (2.08) indicated greater stability. Lower E4/E6 ratios indicate the dominance of aromatic constituents, whereas higher E4/E6 ratios reflect the prominence of aliphatic structures (McDonald et al. 2004). Thus, low E4/E6 in the case of compost produced indicated

Table $2 \mathrm{E}_{4} / \mathrm{E}_{6}$ ratio of compost and manure HA

\begin{tabular}{llll}
\hline & Initial mixture & Produced compost & Manure \\
\hline $\mathrm{E}_{4} / \mathrm{E}_{6}$ & $3.50 \pm 0.03^{\mathrm{a}}$ & $2.27 \pm 0.02^{\mathrm{b}}$ & $2.08 \pm 0.02^{\mathrm{c}}$ \\
\hline
\end{tabular}

that humic fractions extracted from compost produced have the dominance of aromatic constituents. This can be explicated by the occurrence of an oxidation process characteristic of humification (García et al. 2016).

Data are the mean of three replicates. Values followed by different letters are significantly different according to the Duncan test at $P<0.05$.

Infrared spectra showed the same spectra at the beginning and the end of the composting process, indicating a conservation of the basic chemical structures during the composting treatment. Figure $2 \mathrm{~b}$ showed peaks' appearance between $3702 \mathrm{~cm}^{-1}$ and $3600 \mathrm{~cm}^{-1}$. Based on Table 3, these signals indicate the presence of two groups: $\mathrm{Al}-\mathrm{Al}-\mathrm{OH}$ free group O-H of phenols $\left(3650-3600 \mathrm{~cm}^{-1}\right)$ and an aliphatic group. They appeared more intense in the compost-produced spectra.

The two substrates presented a signal around $1700 \mathrm{~cm}^{-1}$ which was more intense in the compost spectra. Date palm compost produced presented amines around $\left(1590 \mathrm{~cm}^{-1}\right)$ and aromatic structures around $\left(1510 \mathrm{~cm}^{-1}\right)$, whereas the initial mixture presented secondary amides around $\left(1540 \mathrm{~cm}^{-1}\right)$.

IR spectra of humic fractions for both initial mixture and compost produced (Fig. 2a) showed a reduction in the structures to $2925 \mathrm{~cm}^{-1}$ and $2840 \mathrm{~cm}^{-1}$, confirming a microbial use of the aliphatic and peptide structures. However, an increase in the etherified and phenolic aromatic structures was confirmed by an increase in the signal around 1642 and $1371 \mathrm{~cm}^{-1}$.

The HA manure spectra presented two groups located in the area around $1700 \mathrm{~cm}^{-1}$ and $1532 \mathrm{~cm}^{-1}$. These signals were relatively more intense in manure than in compost (Fig. 2b). Aromatic structures are developed in the manure, which presented symmetrical and asymmetrical successive bands that were more intense in areas 1673 and $1448 \mathrm{~cm}^{-1}$. For both of the initial mixture and mature compost, infrared spectra were similar and were different just at signals' intensity. This indicates that these materials have similar structures but different functional groups' concentrations.

The signal around $1700 \mathrm{~cm}^{-1}$ is mainly due to the vibrations of double $\mathrm{C}=\mathrm{C}$ in the aromatic structures combined with the carboxylic groupings or carbonyls (Benny et al. 1996). The structural changes indicate biodegradable structures' degradation like polysaccharides, alcohols and acids. This degradation increased aromatic compounds and peptide signals in the palm compost due to micro-organisms activity (Amir et al. 2004). Mature date palm compost can be used as a good amendment.

\section{Soil humic compounds}

Infrared analyses for soil humic compounds (Fig. 3) showed a signal around $3700 \mathrm{~cm}^{-1}$. It was the $\mathrm{OH}-\mathrm{AL}-\mathrm{AL}$ group. A relative intensity increase at $3400 \mathrm{~cm}^{-1}$ is due to stretching 

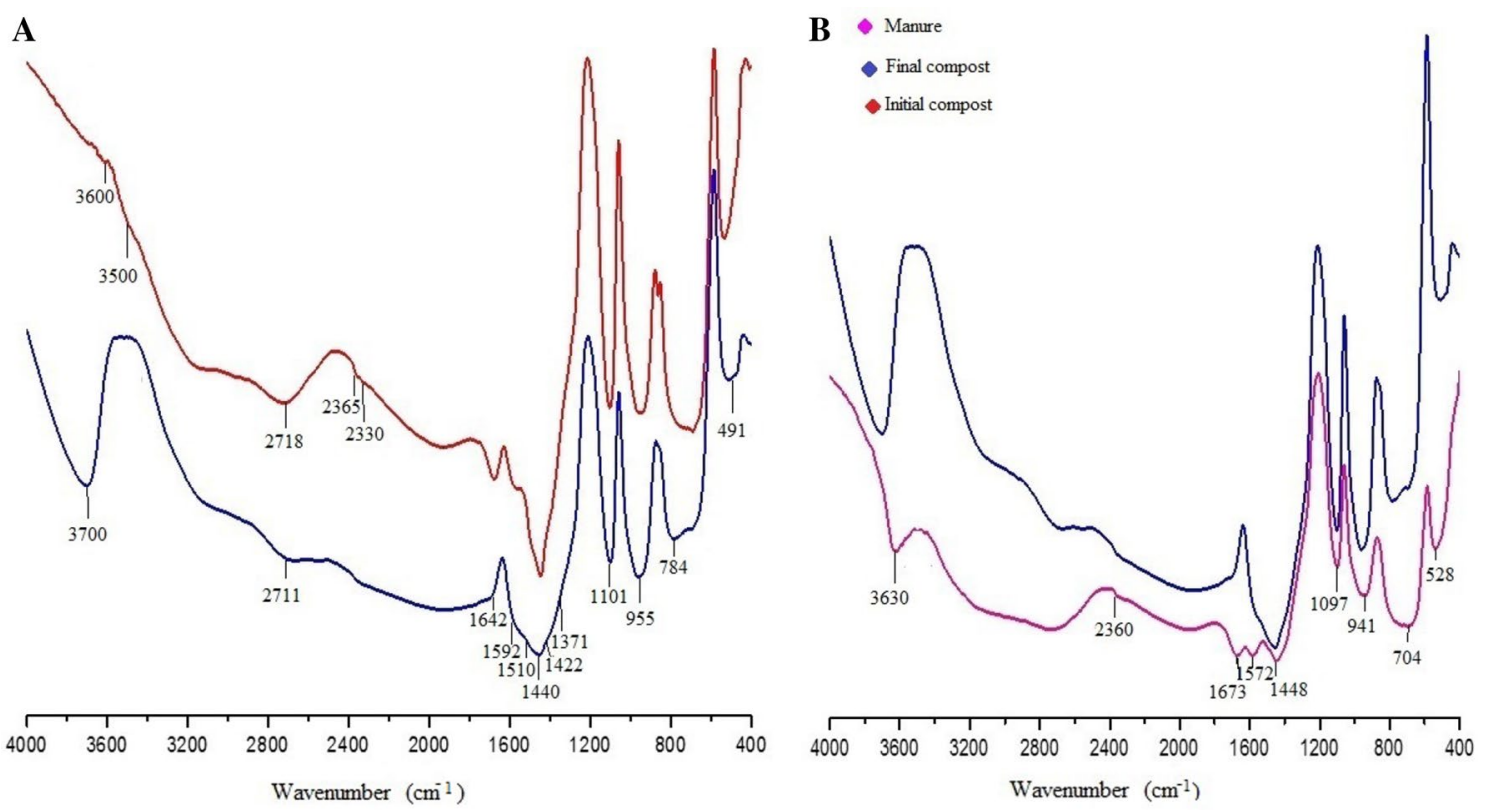

Fig. 2 a Infrared spectra of humic acids extracted from initial mixture and final compost. b Infrared spectra of humic acids extracted from final compost and manure

Table 3 IR bands of major functional groups in humic substances (D'Orazio and Senesi 2009; Abdulla et al. 2010)

\begin{tabular}{lll}
\hline Wavenumbers $\left(\mathrm{cm}^{-1}\right)$ & Vibration & Groups \\
\hline 3400 & $\mathrm{O}-\mathrm{H}$ & Bound and unbound alcohols (AL); water \\
$3180-3090$ & $\mathrm{NH} \mathrm{H}_{2}$ & I Amine \\
$3080-3030$ & $\mathrm{C}-\mathrm{H}$ & $\mathrm{CH}_{2}$ aromatic \\
$2920-2850$ & $\mathrm{C}-\mathrm{H}$ & $\mathrm{CH}_{2}$ et $\mathrm{CH}_{3}$ aliphatic \\
$1740-1720$ & $\mathrm{C}=\mathrm{O}$ & Aldehydes, ketones, carboxylic acids, esters \\
1640 & $\mathrm{C}=\mathrm{O}$ & I Amides, carboxylate \\
& $\mathrm{C}=\mathrm{C}$ & Alkenes, aromatic \\
$1620-1600$ & $\mathrm{C}=\mathrm{C}$ & Aromatic \\
1600 & $\mathrm{~N}-\mathrm{H}$ & Amines \\
$1570-1540$ & $\mathrm{~N}-\mathrm{H}$ & II Amides \\
$1515-1505$ & $\mathrm{C}=\mathrm{C}$ & Aromatic \\
1425 & $\mathrm{COO}-$ & Carboxylic acids \\
1320 & $\mathrm{C}-\mathrm{N}$ & Aromatic I and II amines \\
$1265-1240$ & $\mathrm{C}-\mathrm{O}$ & Carboxylic acids, aryl ethers and phenols \\
& $\mathrm{C}-\mathrm{N}$ & III Amides \\
$1170-1120$ & $\mathrm{C}-\mathrm{OH}$ & Aliphatic alcohols \\
$1080-1010$ & $\mathrm{C}-\mathrm{O}-\mathrm{C}, \mathrm{C}-\mathrm{O}$ & Polysaccharides \\
\hline
\end{tabular}

of vibrations of bound and unbound alcohol and water. Three signals appeared in IR spectra of humic acids under soil mixed with compost characterized by the higher intensity. The signal at $1558 \mathrm{~cm}^{-1}$ was due to stretching vibrations of bands of $\mathrm{N}-\mathrm{H}$ in secondary amides. The higher intensity at this signal was found in the spectra of humic acid under soil with manure. The signal around $1448 \mathrm{~cm}^{-1}$ represented carboxylic acids grouping. The signal around $1286 \mathrm{~cm}^{-1}$ was stretching $\mathrm{C}-\mathrm{OH}$ of aromatic groups and it can be due to the stretching vibrations of ethers and phenols. In spectra of $\mathrm{AH}$ extracted from soil amended by manure, signal at $1650 \mathrm{~cm}^{-1}$ indicated the presence of primary amides carboxylic grouping alkenes, and aromatic groups. Besides, the signal at $1540 \mathrm{~cm}^{-1}$ was due to stretching vibrations of bands of $\mathrm{N}-\mathrm{H}$ secondary amides' groupings. An increase in the signal at $1065 \mathrm{~cm}^{-1}$ indicated the development of polysaccharides' grouping. The IR spectroscopic study of humic acids presents amended soil ray spectra having more intense signals 


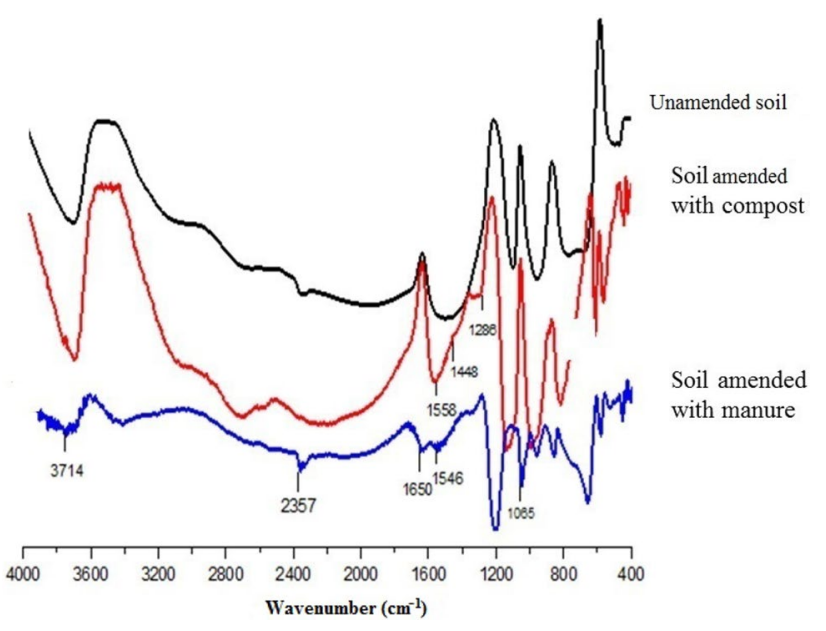

Fig. 3 Infrared spectra of humic acids extracted from unamended and amended soil by manure and compost

in comparison with unamended soil signal including aromatic structures.

These amendments can be used as a source of humic acids' development which largely contributed to soil structure and stability. However, conversely to what was drawn by classical analyses, especially $\mathrm{C}_{\mathrm{AH}} / \mathrm{C}_{\mathrm{AF}}$ ratio, manure induced higher aromatic structures' condensation compared to palm compost. Thus, soil amended with manure has more stable humic compounds and therefore a better impact on the soil structure and life. Despite the differences between compost and manure, both of them induced a high humification degree.

\section{Conclusion}

The humic components' evolution in the soil in relation with manure and compost application and compost quality are complex and cannot be found by one parameter. Results showed that compost maturity could be evaluated by several parameters: $6<\mathrm{pH}<8, \mathrm{C} / \mathrm{N}$ ratio $<15, \mathrm{C}_{\mathrm{HA}} / \mathrm{C}_{\mathrm{FA}}$ ratio $>1$. IR spectroscopy of humic compounds extracted from compost indicated that aromatic structures increased by the composting process. Thus, improving aromatic structures is an indication of compost maturity. The application of compost to soil showed a slight change in physicochemical properties and fertility levels by higher levels of organic matter, phosphorus and calcium and also by a marked improvement of humification rate. IR spectroscopic analyses applied on amended soils with compost and manure showed a better condensation and polymerization of humic substances. Land application of compost palm waste for a short term provides organic matter nutrients, and improves aromatic structures in sandy soils, especially that sandy soil has high infiltration rates and retains little water. Date palm compost can be useful as an alternative solution to improve soil quality and to prevent environment pollution from waste accumulation.

Acknowledgements This work was carried out in the Olive Tree Institute. The facilities and services of the Institut de l'Olivier are gratefully acknowledged. It was supported by the Ministry of Agriculture and Water Resources and the Ministry of Higher Education and Scientific Research. Special acknowledgement to the members of composting unit located in the oasis of Chenini Nahel Tunisia.

Open Access This article is distributed under the terms of the Creative Commons Attribution 4.0 International License (http://creativeco mmons.org/licenses/by/4.0/), which permits unrestricted use, distribution, and reproduction in any medium, provided you give appropriate credit to the original author(s) and the source, provide a link to the Creative Commons license, and indicate if changes were made.

\section{References}

Abdulla HAN, Minor EC, Dias RF, Hatcher PG (2010) Changes in the compound classes of dissolved organic matter along an estuarine transect: a study using FTIR and 13C NMR. Geochim Cosmochim Acta 74(13):3815-3838. https://doi.org/10.1016/j. gca.2010.04.006

Ali YSS (2008) Use of date palm leaves compost as a substitution to peatmoss. Am J Plant Physiol 3(4):131-136. https://doi. org/10.3923/ajpp.2008.131.136

Amir S, Hafidi M, Bailly JR, Revel JC (2003) Characterization of humic acids extracted from sewage sludge during composting and their Sephadex gel fractions. Agronomie 23:269-275. https://doi. org/10.1051/agro:2002090

Amir S, Hafidi M, Merlina G, Hamdi H, Revel JC (2004) Elemental analysis, FTIR and 13C-NMR of humic acids from sewage sludge composting. Agronomie 24:13-18. https://doi.org/10.1051/ agro:2003054

Aparna C, Saritha P, Himabindu V, Anjaneyulu Y (2008) Techniques for the evaluation of maturity for composts of industrially contaminated lake sediments. Waste Manag 28:1773-1784. https:// doi.org/10.1016/j.wasman.2007.07.008

Bastida F, Kandeler E, Hernández T, García C (2008) Long-term effect of municipal solid waste amendment on microbial abundance and humus-associated enzyme activities under semiarid conditions. Microb Ecol 55:651-661. https://doi.org/10.1007/s0024 8-007-9308-0

Benabderrahim MA, Elfalleh W, Belayadi H, Haddad M (2018) Effect of date palm waste compost on forage alfalfa growth, yield, seed yield and minerals uptake. Int J Recycl Org Waste Agri 7:1-9. https://doi.org/10.1007/s40093-017-0182-6

Benny C, Patrick Hatchery G, Hagar Y, Chen Y (1996) Chemical and biological characterization of organic matter during composting of municipal solid waste. J Environ Qual 25:776-785. https://doi. org/10.2134/jeq1996.00472425002500040018x

Brady NC, Weil RR (2005) The nature and properties of soils, 13th edn. Macmillan Publishing Company, New York, pp 279-313

Conant RT, Ryan MG, Agren GI, Birge HE, Davidson EA, Eliasson PE, Evans SE, Frey SD et al (2011) Temperature and soil organic matter decomposition rates-synthesis of current knowledge and a way forward. Glob Change Biol 17:3392-3404. https://doi.org/ 10.1111/j.1365-2486.2011.02496.x

Dikinya O, Mufwanzala N (2010) Chicken manure-enhanced soil fertility and productivity: effects of application rates. J Soil Sci Environ Manag 1:46-54 
D’Orazio V, Senesi N (2009) Spectroscopic properties of humic acids isolated from the rhizosphere and bulk soil compartments and fractionated by size-exclusion chromatography. Soil Biol Biochem 41:1775-1781. https://doi.org/10.1016/j.soilbio.2008.02.001

Eghball B (2001) Composting Manure and other organic residue. Cooperative Extension Publication (NebGuide), Ed. Institute of Agriculture and Natural Resources. University of Nebraska, Lincoln, USA

Franco-Otero VC, Soler-Rovira P, Hernández D, López-De-Sá E, Plaza CS (2011) Short-term effects of organic municipal wastes on wheat yield, microbial biomass, microbial activity, and chemical properties of soil. Biol Fertil Soils. 48(2):205-216. https://doi. org/10.1007/s00374-011-0620-y

García AC, Souza GA, Pereira MG, Castro RM, García-Mina JM, Zonta E et al (2016) Structure-property-function relationship in humic substances to explain the biological activity in plants. Sci Rep 6:20798. https://doi.org/10.1038/srep20798

García-Gil JC, Ceppi SB, Velasco MI, Polo A, Senesi N (2004) Longterm effects of amendment with municipal solid waste compost on the elemental and acidic functional group composition and pH-buffer capacity of soil humic acids. Geoderma 121:135-142. https://doi.org/10.1016/j.geoderma.2003.11.004

Gargouri K, Rigane H, Arous I, Touil F (2013) Evolution of soil organic carbon in an olive orchard under arid climate. Sci Hortic 152:102-108. https://doi.org/10.1016/j.scienta.2012.11.025

Gobat JM, Aragno M, Matthey W (1998) Les propriétés du sol. Le sol vivant, Presses polytechniques et universitaire romandes, Lausanne, p p519

Haddad G, El-Ali F, Mouneimne AH (2015) Humic Matter of Compost: determination of Humic Spectroscopic Ratio (E4/E6). Curr Sci Int 4:56-72

Hemmat A, Aghilinategh N, Rezainejad Y, Sadeghi M (2010) Longterm impacts of municipal solid waste compost, sewage sludge and farmyard manure application on organic carbon, bulk density and consistency limits of a calcareous soil in central Iran. Soil Tillage Res 108(1-2):43-50. https://doi.org/10.1016/j.still .2010.03.007

Heras J, Manas P, Labrador J (2005) Effects of several applications of digested sewage sludge on soil and plants. J Environ Sci Health A Tox Hazard Subst Environ Eng 40:437-451. https:// doi.org/10.1081/ESE-200045646

Hernandez TC, Garcia JA, Pascual, Moreno JL (2001) Humic acids from various organic wastes and more traditional organic matter: effect on plant growth and nutrient absorption. In: Swift RS, Spark KM (eds) Understanding and managing organic matter in soils, sediments and waters. Proceeding of the 9th international conference of the International Humic Substances Society University of Adelaide, Adelaide, Australia, 21st-25th September 1998

Horwath W (2015) Carbon cycling: the dynamics and formation of organic matter. In: Paul EA (ed) Soil micro, eco and bioche, 4th edn. Academic Press, New York, pp 339-382

Jemagne M (1967) Bases et techniques d'une cartographie des sols. Ann Agron 18:p142

Khiyami M, Masmali I, Abu-khuraiba M (2008) Composting a mixture of date palm wastes, date palm pits, shrimp, and crab shell wastes in vessel system. Saudi J Biol Sci 15(2):199-205

Kouki K, Bouhaouach H (2009) Etude de l'oasis traditionnelle Chenini Gabès dans le Sud Est de la Tunisie. Tropicultura 27:93-97

Lakhdar A, Rabhi M, Ghnaya T, Montemurro F, Jedidi N, Abdelly C (2009) Effectiveness of compost use in salt-affected soil. J Hazard Mater 171:29-37. https://doi.org/10.1016/j.jhazmat.2009.05.132

Mcdonald S, Bishop AG, Prenzler PD, Robards K (2004) Analytical chemistry of freshwater humic substances. Anal Chim Acta 527:105-124. https://doi.org/10.1016/j.aca.2004.10.011
Ouatmane A, D’Orazio V, Hafidi M, Senesi N (2002) Chemical and physicochemical characterization of humic-acid like materials from compost. Compost Sci Util 10:39-46. https://doi. org/10.1080/1065657X.2002.10702061

Pauwels JM, Van Ranst E, Verloo M, MvondoZe A (1992) Manuel de laboratoire de pedologie. Public. Agric 28:75-126

Raj D, Antil RS (2011) Evaluation of maturity and stability parameters of composts prepared from agro-industrial wastes. Bioresour Technol 102:2868-2873. https://doi.org/10.1016/j.biort ech.2010.10.077

Rigane MK, Medhioub K (2011) Assessment of properties of Tunisian agricultural waste composts: application as components in reconstituted anthropic soils and their effects on tomato yield and quality. Resour Conserv Recycl 55:785-792. https://doi.org/10.1016/j. resconrec.2011.03.012

Rivero C, Senesi N, Paolini J, D'Orazio V (1998) Characteristics of humic acids of some venezuelan soils. Geoderma 81:227-239. https://doi.org/10.1016/S0016-7061(97)00110-9

Rivero C, Chirenje T, Ma LQ, Martinez G (2004) Influence of compost on soil organic matter quality under tropical conditions. Geoderma 123:355-361. https://doi.org/10.1016/j.geoderma.2004.03.002

Sarwar G, Hussain N, Mujeeb F, Schmeisky H, Hassan G (2003) Biocompost application for the improvement of soil characteristics and dry matter yield of Lolium perenne (Grass). Asian J Plant Sci 2:237-241. https://doi.org/10.3923/ajps.2003.237.241

Sellami F, Hachicha S, Chtourou M, Medhioub K, Ammar E (2008) Maturity assessment of composted olive mill wastes using UV spectra and humification parameters. Bioresour Technol 99:69006907. https://doi.org/10.1016/j.biortech.2008.01.055

Serrano-Ortiz P, Roland M, Sanchez-Moral S, Janssens IA, Domingo F, Goddéris Y, Kowalski AS (2010) Hidden, abiotic $\mathrm{CO}_{2}$ flows and gaseous reservoirs in the terrestrial carbon cycle: review and perspectives. Agric For Meteorol 150:321-329. https://doi. org/10.1016/j.agrformet.2010.01.002

Stangel PJ (1991) Plant nutrients in sustainable land management systems. In: International workshop on evaluation for sustainable land management in the developing world. Chiangrai, Thailand

Tchegueni S, Koriko M, Koledzi E, Bodjona BM, Kili A, Tchangbedji G, Baba G, Hafidi M (2013) Physicochemical characterization of organic matter during co-composting of shea-nut cake with goat manure. Afr J Biotechnol 12:3466-3471. https://doi.org/10.5897/ ajb12.2192

Tomati U, Madejon E, Galli E, Capitani D, Serge AL (2001) Structural changes of humic acids during olive mill pomace composting. Compost Sci Util 9:134-142. https://doi.org/10.1080/10656 57X.2001.10702027

Ultra VU Jr, Mendoza DM, Briones AM (2005) Chemical changes under aerobic composting and nutrient supplying potential of banana residue compost. Renew Agric Food Sci 20:113-125. https://doi.org/10.1079/RAF2005104

Valarini PJ, Alvarez D, Gasco MJ, Guerrero MF, Tokeshi H (2003) Assessment of soil properties by organic matter and em-microorganism incorporation. Rev Bras Ciênc Solo 27:519-525. https:// doi.org/10.1590/S0100-06832003000300013

Visser SM, Sterk G (2007) Nutrient dynamics - wind and water erosion at the village scale in the Sahel. Land Degrad Dev 18(5):578-588. https://doi.org/10.1002/ldr.800

Xu Y, Chen W, Shen Q (2007) Soil organic carbon and nitrogen pools impacted by long-term tillage and fertilization practices. Commun Soil Sci Plant Anal 38:347-357. https://doi.org/10.5601/ jelem.2017.22.1.1264

Publisher's Note Springer Nature remains neutral with regard to jurisdictional claims in published maps and institutional affiliations. 